\title{
Fruit growth and proximate composition of deshi (Diospyros peregrina) and bilati gab (D. discolor)
}

\author{
M. M. Hasan¹, M. S. A. Fakir*, M. M. Rahman and S. Naznin \\ Department of Crop Botany, Bangladesh Agricultural University, Mymensingh, ${ }^{1}$ Department of Crop Botany \& Tea \\ Production Technology, Sylhet Agricultural University, Sylhet, *Email: fakirmsa @ yahoo. com
}

\begin{abstract}
Fruit (berry) growth, maturity and nutritional composition of deshi (Diospyros peregrina Gurke) and bilati Gab (D. discolor Gurke) were investigated at the Botanical Garden of Bangladesh Agricultural University, Mymensingh (24 ${ }^{\circ} 26^{\prime}$ and $24^{\circ} 54^{\prime} \mathrm{N}$ and $90^{\circ} 15^{\prime}$ and $90^{\circ} 30^{\prime} \mathrm{E}$ ) between April and August, 2011. Flowers were tagged at first opening (days after flowering, DAF) and fruit growth was investigated up to maturity. Fruit size (length and diameter), individual fruit weight, AGR and proximate composition of matured fruits were investigated. Morphological and growth parameters were recorded at 7-days interval up to 63 DAF in deshi and 85 DAF in bilati gab. All the morphological characters of fruits were gradually increased with increasing DAF and followed sigmoid pattern. The length and diameter of the berry became 5.80 and $4.61 \mathrm{~cm}$, respectively at $63 \mathrm{DAF}$ in deshi gab, and 9.13 and $7.62 \mathrm{~cm}$, respectively at $85 \mathrm{DAF}$ in bilati gab. The fresh and dry weights of berries were also maximum at $63 \mathrm{DAF}$ in deshi and at 85 DAF in bilati gab. The maximum dry weight of seed i.e. PM in deshi gab attained at 56 DAF and that of bilati gab at 83 DAF. The proximate composition of matured berries of deshi and bilati gab at PM showed little variation between the species and hence, average crude protein, crude fat, ash and total carbohydrate was 5.35, $1.08,3.74$ and $67.47 \%$, respectively. It might be concluded that harvest maturity attained around two months after flowering in deshi gab with yellowish green colour on fruit coat and three months from flowering in bilati gab when fruits turn into deep red colour with average fruit fresh weight of $60 \mathrm{~g}$ and $220 \mathrm{~g}$, respectively.
\end{abstract}

Key words: Diospyros peregrina, Fruit growth, Maturity indicator, Proximate composition

\section{Introduction}

Deshi gab (Diospyros peregrina Gurke) is a minor, tropical edible fruit belongs to family Ebenaceae. It is evergreen, dioecious tree. Flowers are small, unisexual and incomplete with persistent calyx. The sticky pulp of fruit is extensively used to smear with fishing nets to make them durable under water. The peak flowering and fruiting season ranges from April to June (Das and Alam, 2001). The blackish cover of berries gradually disappear indicating fruit maturity. Bilati gab ( $D$. discolor Gurke) is another minor tropical fruit belongs to the same family and is originated from Philippines (Singh, 1998). This fruit is found in the district of Kushtia, Jessore, Faridpur, Rajshahi, Barisal, Pirozpur, and Chittagong Hill Tracts region of Bangladesh. The fruit is very attractive for its beautiful reddish colour at maturity. Immature fruits are astringent, while ripe fruits have sweet smell and are eaten as table fruits (Ahmed et al. 2011). Fruits are nutritionally rich that contain (per $100 \mathrm{~g}$ of edible portion) calories 113, water $69.6 \mathrm{~g}$, carbohydrates 26.6 $\mathrm{g}$, fibre $1.5 \mathrm{~g}$, fat $0.1 \mathrm{~g}$, protein $1.4 \mathrm{~g}$, minerals $0.8 \mathrm{~g}$, calcium $58 \mathrm{mg}$ (Mondal, 2000). Mature leaves of deshi and bilati gab are reported to be edible (Sankar, Pers. comm.).

Harvesting of fruits at the right time will ensure better storage life as well as fruit quality. Usually fruits mature when the seeds attain physiological maturity i.e. PM (Rahman et al. 2010, Roy et al. 2010). Identification of physiological maturity, therefore, is important to preserve seed and to obtain high quality of fruit. In general, maturation is accompanied by significant changes in external appearance (Proctor and Caygill, 1985). Any fruit picked either early or too late is more susceptible to physiological disorders or has a shorter shelf life than fruit picked at the proper maturity (Kader, 1999). There is little published information on morphological features (Das and Alam, 2001) and only a couple of researches on growth of minor fruits such as in cowphal (Garcinia cowa) (Roy et al. 2010) and china cherry (Muntingia calabura) (Rahman et al. 2010) is available in Bangladesh. There is only one report on fruit growth and maturity in deshi and bilati gab (Hasan, 2012). To obtain maximum yield and ensure better quality, knowledge on fruit growth and maturity is very important. So, the study was carried out (i) to investigate the growth of fruit; and (ii) to determine the nutritional value of the fruit and leaf. Overall objective was to ascertain the right stage of fruit harvest. 


\section{Materials \& Methods}

Three deshi gab and three bilati gab trees were selected in Botanical Garden, Bangladesh Agricultural University, Mymensingh to study growth and development of fruits during April to August, 2011. Different coloured woolen threads were loosely fastened in the pedicel of flowers to record fruit age at $0,7,14,21$, $28,35,42,49,56,60$ and 63 days after first opening of flowers (DAF) in deshi gab and at $0,7,14,21,28$, $35,42,49,56,63,70,77,83$ and $85 \mathrm{DAF}$ in bilati gab. In deshi gab, tagging of flowers was started at 25th April and continued till end of May, while in bilati gab, tagging started at 22th May and continued up to end of June. At each DAF, at least 20 fruits (four replication, five in each replicate) were harvested and measured for fruit length, diameter, fresh and dry weight of pulp and seed. The length and diameter of fruits were measured using threads and ruler. Freshly harvested fruits of deshi and bilati gab were shelled and the seeds were separated. The dry weight of pericarp and seed were recorded after oven drying $\left(80 \pm 2^{0} \mathrm{C}\right)$ till constant weight. The absolute growth rate (AGR) of fruit was also calculated. The proximate constituents: crude protein (CP), crude fibre (CF), ether extract (EE) or crude fat, ash and nitrogen free extract (NFE) or total carbohydrate of matured berries of deshi and bilati gab were determined at 56 and 83 DAF, respectively (AOAC, 1990). The Randomized Complete Block Design (RCBD) was followed with four replications. Different ages i.e. DAF were used as treatment in analyzing the Data. The mean differences were compared by least significant difference (LSD) test (Gomez and Gomez, 1984).

\section{Results}

\section{Deshi Gab}

Fruit size: Fruit length and diameter followed a double sigmoid pattern and increased with increasing ages (days after flowering, DAF) (Fig. 1A). The length was $1.60 \mathrm{~cm}$ at $7 \mathrm{DAF}$ and grew rapidly and reached $2.37 \mathrm{~cm}$ at 14 DAF followed by a plateau between 21 and 28 DAF. Fruit length gradually increased at a rapid rate up to $49 \mathrm{DAF}$ when length was $5.40 \mathrm{~cm}$. The length further increased followed by a plateau up to maturity (63 DAF) with fruit length of $5.80 \mathrm{~cm}$. Fruit diameter was $1.55 \mathrm{~cm}$ at $7 \mathrm{DAF}$ and increased sharply up to $14 \mathrm{DAF}(2.45 \mathrm{~cm})$ followed by a gradual increase up to $63 \mathrm{DAF}$, when diameter was $4.61 \mathrm{~cm}$ (Fig. 1A).

Pulp weight: Pulp fresh weight followed a sigmoid pattern while dry weight followed almost a linear pattern (Fig. 1C). Pulp fresh weight was $1.14 \mathrm{~g}$ at $7 \mathrm{DAF}$ and increased linearly up to $18.28 \mathrm{~g}$ (42 DAF) followed by a sharp increase up to $56 \operatorname{DAF}(39.75 \mathrm{~g})$. Fresh weight followed a plateau up to maturity when weight was $47.02 \mathrm{~g}$ at $63 \mathrm{DAF}$. Pulp dry weight was $0.25 \mathrm{~g}$ at $7 \mathrm{DAF}$ and linearly increased to $8.03 \mathrm{~g}$ till maturity (Fig. 1C).

Seed weight: Seed fresh weight also followed a sigmoid pattern while dry weight followed almost a linear pattern (Fig. 1E). Seed fresh weight was $0.06 \mathrm{~g}$ at $7 \mathrm{DAF}$ and increased linearly up to $6.78 \mathrm{~g}$ (49 DAF) followed by a sharp increase up to $56 \mathrm{DAF}(9.11 \mathrm{~g})$. Fresh weight followed a plateau up to maturity when weight was $10.05 \mathrm{~g}$ at $63 \mathrm{DAF}$. Pulp dry weight was $0.02 \mathrm{~g}$ at $7 \mathrm{DAF}$ and almost increased linearly to 3.22 g till maturity (Fig. 1E).

\section{Bilati Gab}

Fruit size: Fruit length and diameter followed a double sigmoid pattern (Fig 1B). At 7 DAF fruit length was $0.61 \mathrm{~cm}$ and slowly increased to $35 \mathrm{DAF}(2.05 \mathrm{~cm})$ followed by a rapid increased up to $83 \mathrm{DAF}(9.08 \mathrm{~cm})$ and became plateau towards maturity. Fruit diameter gradually increased towards maturity and it was $6.85 \mathrm{~cm}$ at $77 \mathrm{DAF}$ and reached to $7.62 \mathrm{~cm}$ at $85 \mathrm{DAF}$ (Fig 1B).

Pulp weight: Pulp fresh weight followed a sigmoid pattern (Fig. 1D). Fresh weight slowly increased from 7 to $35 \mathrm{DAF}$ followed by a rapid increase up to $77 \mathrm{DAF}(165 \mathrm{~g})$ and slowly increased till maturity. Pulp dry weight increased very slowly up to $42 \mathrm{DAF}$ and also with slowly growth towards maturity (Fig. 1D).

Seed weight: Seed fresh weight and dry weight followed a double sigmoid growth pattern (Fig. 1F). At early growth stage fresh weight increased slowly but from 35 DAF it increased very rapidly up to 77 DAF followed by a plateau at the end of fruit growth. Seed dry weight increased very slowly up to 49 DAF followed by a rapid increased towards maturity (Fig. 1F). 

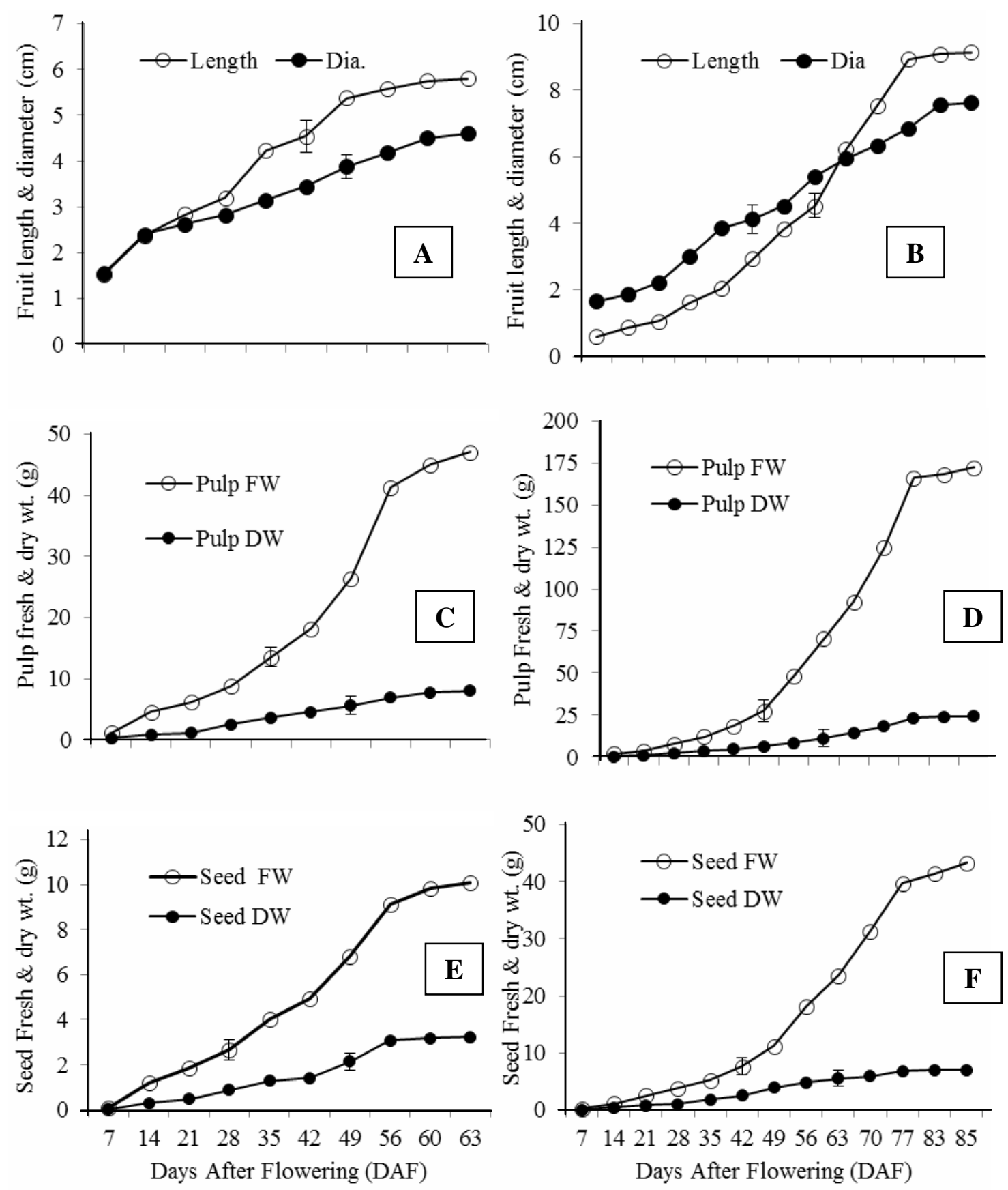

Fig. 1. Changes in fruit size $(A, B)$, pulp weight $(C, D)$, and seed weight $(E, F)$ in deshi gab $(A, C$ and $E)$ and bilati gab $(B, D$ and $F)$ at different ages (DAF). Vertical bars indicate Isd $_{0.05}$.

Fruit absolute growth rate (AGR): Effect of ages (days after flowering, DAF) on AGR of fruit was significant $(P \leq 0.05)$ both in deshi and bilati gab (Table 1). The AGR was significantly greater between 49 and $56 \mathrm{DAF}$ (average of $0.17 \mathrm{~g} /$ day) in deshi gab and between 63 and $70 \mathrm{DAF}$ (average of $0.75 \mathrm{~g} / \mathrm{day}$ ) in bilati gab than in other DAFs. The AGR gradually reached to maximum in both species and again declined towards maturity. 
Table 1. Variation in absolute growth rate (AGR) of fruit of deshi and bilati gab at different ages (days after flowering, DAF)

\begin{tabular}{|l|c|c|c|}
\hline Age (DAF) & AGR (g/day) of deshi gab & Age (DAF) & AGR (g/day) of bilati gab \\
\hline $0-7$ & $0.03 \mathrm{f}$ & $0-7$ & $0.02 \mathrm{~m}$ \\
\hline $7-14$ & $0.09 \mathrm{e}$ & $7-14$ & $0.06 \mathrm{l}$ \\
\hline $14-21$ & $0.11 \mathrm{~cd}$ & $14-21$ & $0.08 \mathrm{k}$ \\
\hline $21-28$ & $0.10 \mathrm{de}$ & $21-28$ & $0.11 \mathrm{j}$ \\
\hline $28-35$ & $0.12 \mathrm{c}$ & $28-35$ & $0.15 \mathrm{i}$ \\
\hline $35-42$ & $0.14 \mathrm{~b}$ & $35-42$ & $0.22 \mathrm{~h}$ \\
\hline $42-49$ & $0.15 \mathrm{~b}$ & $42-49$ & $0.35 \mathrm{~g}$ \\
\hline $49-56$ & $0.17 \mathrm{a}$ & $49-56$ & $0.51 \mathrm{e}$ \\
\hline $56-60$ & $0.12 \mathrm{c}$ & $56-63$ & $0.63 \mathrm{c}$ \\
\hline $60-63$ & $0.09 \mathrm{e}$ & $63-70$ & $0.75 \mathrm{a}$ \\
\hline- & - & $70-77$ & $0.69 \mathrm{~b}$ \\
\hline- & - & $77-83$ & $0.58 \mathrm{~d}$ \\
\hline- & - & $83-85$ & $0.45 \mathrm{f}$ \\
\hline $\mathbf{I s d}_{0.05}$ & $\mathbf{0 . 0 1 4}$ & $\mathbf{I s d}_{0.05}$ & $\mathbf{0 . 0 1 4}$ \\
\hline
\end{tabular}

In each column, figures bearing uncommon letter(s) are significantly different at $P \leq 0.05$. Each figure is the mean of 20 fruits (5 fruit $\times 4$ replications).

Proximate Composition of fruit: There were little variation in proximate composition except crude fibre content and it was higher in bilati gab (17.97\%) than deshi gab $(6.71 \%)$ (Table 2$)$. Therefore, both the fruits possess good nutrition in terms of proximate composition.

Proximate Composition of leaf: Crude protein (CP) appeared similarly between deshi and bilati gab and contained an average of $11.62 \%$ (Table 2). Trend of crude fibre (CF) was similar to CP with an average of 22.76\%. Ether extract (EE) and total carbohydrate (NFE) were higher in bilati gab (6.06 and 46.45\%, respectively) but ash content was greater in deshi gab (8.87\%) (Table 2).

Table 2. Proximate composition (crude protein, crude fibre, ether extract, ash and total carbohydrate) of matured fruits at PM and leaves in deshi and bilati gab

\begin{tabular}{|l|c|c|c|c|c|}
\hline \multirow{2}{*}{ Crop } & \multicolumn{5}{|c|}{ Proximate Composition of fruit at PM (\%) } \\
\cline { 2 - 6 } & CP & CF & EE & Ash & NFE \\
\hline Deshi gab (56 DAF) & 4.84 & 6.71 & 1.08 & 3.24 & 70.51 \\
\hline Bilati gab (83 DAF) & 5.86 & 17.97 & 1.08 & 4.23 & 64.43 \\
\hline t-test & NS & $\star *$ & NS & NS & NS \\
\hline & \multicolumn{5}{|c|}{ Proximate Composition of mature leaf (\%) } \\
\hline Deshi gab & 13.61 & 19.25 & 6.06 & 6.26 & 46.45 \\
\hline Bilati gab & 9.63 & 26.76 & 4.46 & 8.87 & 43.07 \\
\hline t-test & NS & NS & $\star *$ & $\star *$ & $*$ \\
\hline
\end{tabular}

${ }^{* *}=$ Significant at $1 \%$ level of probability, NS= Non significant

\section{Discussion}

Growth characteristics of fruits and seeds were studied to identify the maturity stage of deshi (Diospyros peregrina) and bilati gab ( $D$. discolor). Deshi gab produces numerous berries used for dying fishing net and boat,and the fruit of bilati gab is edible. These minor fruits are lesser known in our sub-continent and could be important sources of dye and edible fruits in Bangladesh. Fruit size (length and diameter) of deshi and bilati gab increased with increasing ages (days after flowering, DAF). Fruit size of deshi and bilati gab followed a double sigmoid growth pattern and this type of growth is also found in $D$. kaki (Glucina and Toye, 1985). Fruit length and diameter became maximum at 63 and 85 DAF in deshi and 
bilati gab, respectively (Fig. 1A and 1B). Fruits attained an approximate weight of $56 \mathrm{~g}$ at $56 \mathrm{DAF}$ and 210 $\mathrm{g}$ at $83 \mathrm{DAF}$, and remained more or less unchanged till 63 and $85 \mathrm{DAF}$ in deshi and bilati gab (Fig. 1C and 1D), respectively indicating maximum fruit size. This indicates harvest maturity of these two fruits. The present result regarding fruit size (length and diameter of 9.13 and $7.62 \mathrm{~cm}$, respectively) and weight $(220 \mathrm{~g})$ of bilati gab is in partial conformity with the report of Ahmed et al. (2011) who reported that fruit length and diameter of velvet apple (D. discolor) ranged from 6.63 to $7.7 \mathrm{~cm}$ and 5.73 to $8.3 \mathrm{~cm}$, respectively with single fruit weight 118 to $283 \mathrm{~g}$. In deshi gab, pulp fresh and dry weight reached maximum (47.02 and $8.03 \mathrm{~g} /$ fruit, respectively) around two months from flowering (63 DAF) and that of bilati gab, three months after flowering (85 DAF) (182.44 and $32.33 \mathrm{~g} /$ fruit, respectively) (Fig. 1C \& 1D) that again suggest the harvesting stage of the fruits. The maximum dry weight of seeds is known as physiological maturity (PM) and it is more or less accompanied by fruit ripening maturity. In deshi gab, PM of seed attained at $56 \mathrm{DAF}$ which was followed by higher pulp fresh weight at $60 \mathrm{DAF}$ (Fig. 1C and 1E). Again in bilati gab, PM of seeds attained at 83 DAF followed by higher pulp weight at 85 DAF (Fig. 1D and $1 \mathrm{~F}$ ). This feature indicates that PM and fruit maturity attained at around same time. Not only the fruit size but also the AGR also became maximum at PM in deshi gab $(0.17 \mathrm{~g} / \mathrm{day})$ which again indicates fruit maturity but in bilati gab similar trend was not found. The current results are similar with the fruit maturity and PM at around 63 DAF in cowphal (Roy et al. 2010), and around 53 DAF in China cherry (Rahman et al. 2010). Proximate composition is also considered as a predictor of fruit maturity in terms of nutritional quality (Roy et al. 2010; Rahman et al. 2010). Fruits of deshi and bilati gab contained appreciable amount of crude protein, crude fibre and total carbohydrate (average of $5.35,12.34$ and $67.47 \%$, respectively) (Table 2). Matured leaves of deshi and bilati gab also contained good amount of crude protein, crude fibre and total carbohydrate (average of 11.62, 23.00 and $44.76 \%$, respectively) (Table 2). Therefore, leaves of both trees could be a potential source of fodder. Around two months from flowering, a berry of deshi gab turn yellowish green with the loss of blackish hairs, which is developed earlier on fruit surface (observation) and that of bilati gab, after three months from flowering, fruits turn into dark red colour indicating visual index of fruit harvest. These indices are important for harvesting berries at right time to ensure good fruit quality. People usually use visual indicator to harvest fruits and in most fruits the physical appearance changed at maturity. Changes in visual appearance of fruits have also been reported in D. kaki (Yamazaki et at. 1981; Suzuki et al. 1981), D. blancoi and D. mespiliformis (Janick and Paull, 2008), China cherry (Rahman et al. 2010) and cowphal (Roy et al. 2010). It might be concluded that deshi and bilati gab attained maturity at about two and three months from flowering, respectively with good nutrients.

\section{Acknowledgements}

We gratefully acknowledge the help of Mr. Habib for tagging flowers and Head of the Department of Animal Nutrition for access to proximate analyses. Thanks are also due to NST fellowship offered in 2011-'12 to the first author from The Ministry of Science and Technology, GoB.

\section{References}

Ahmed, M., Mozumder, S.N., Firoz, Z.A. and Faisal, S.M. 2011. Variability and performance of superior velvet apple (Diospyros discolor) germplasm in hilly region. Bangladesh J. Agril. Res. 36(2): 223-230.

AOAC (Association of Official Analytical Chemists). 1990. Official Methods of Analysis: Agricultural Chemicals; Contaminants; Drugs. $\left(15^{\text {th }}\right.$ Ed.) .Vol. 1. Arlington, Virginia. p. 58.

Das, D.K. and Alam, M.K. 2001. Trees of Bangladesh, Bangladesh Forest Res. Inst., Chittagong. pp. 83, 116-118, 155-156.

Glucina, P.G. and Toye, J.D. 1985. Flower bud and fruit development of persimmons. Proceedings Raukura Horticultural Conference (persimmon). Hamilton, New Zealand, Ministry of Agriculture and Fisheries. pp. 11-14.

Gomez, K.A. and Gomez, A.A. 1984. Statistical Procedures for Agricultural Research. John Wiley and Sons, New York. pp. 97-111.

Hasan. M.M. 2012. Flower morphology and fruit growth in deshi gab (Diospyros peregrina) and bilati gab (D. discolor). MS Thesis, Dept. of Crop Botany, Bangladesh Agric. University, Mymensingh. pp. 19-23.

Janick, J and Paull, R.E. 2006 (Eds.). The encyclopedia of fruits \& nuts. Cambridge University Press, Cambridge. pp. 323-325. 
Kader, A.A. 1999. Fruit maturity, ripening and quality relationships. Proc. Int. Symp. on Effect of Pre and Post-Harvest Factors on Storage of Fruit. Acta Hort. pp. 203-208.

Mondal, M.F. 2000. Production and Storage of Fruits (in Bangla). Mrs. Afia Mondal, BAU Campus, Mymensingh-2202. p. 212.

Proctor, F.J. and Caygill, J.C. 1985. Proc. 39 $9^{\text {th }}$ Easter School, University of Nottingham, UK. pp. 317-322.

Rahman, M.M., Fakir, M.S.A. and Rahman, M.M. 2010. Fruit Growth in China cherry (Muntingia calabura). Botany Res. International. 3(2): 56-60.

Roy, D.K., Fakir, M.S.A., Rahman, M.M. and Rahman, M.M. 2010. Fruit growth in cowphal (Garcinia cowa). J. Agrofor. \& Environ. 3(2): 57-59.

Singh, R. 1998. Fruits. National Book Trust, A-5, Green Park, New Delhi, India. p. 200.

Suzuki, T., Yamazaki, T., Murase, S., Miyagawa, H., Nogata, T., Mitobe, M. and Morita, A. 1981. Bull. Fruit Tree Res. Station, Yatabe, Ibaraki, Japan. 8: 85-100.

Yamazaki, T., Suzuki, T., Murase, S. and Otake, S. 1981. Bull. Fruit Tree Res. Station, Yatabe, Ibaraki, Japan. 8: $79-84$. 